\title{
Living and Eating Behavior before and after Metabolic Surgery in Romanian Patients
}

\author{
Mihai IONESCU ${ }^{7}$, Radu Mihail MIRICA ${ }^{2,3}$, Razvan IOSIFESCU ${ }^{2,3}$, Andrei VACARASU ${ }^{2}$, Petru PETRISOR ${ }^{1}$
}

\begin{abstract}
Introduction: Obesity is currently an endemic problem worldwide largely caused by an environment that promotes excessive food consumption and discourages physical activity. The sources of obesity are directly related to two areas: genetic and environmental factors, which constantly interact in the regulation of body weight. Aim: Through this research, it was aimed to evaluate the typical profile of the individual who uses metabolic surgery and the degree of physical and psychological satisfaction after such an intervention. Materials and methods: The patients introduced in the study are from personal cases, in number of about 1130, operated during 9 years. Of these, 122 represented the basis for the analysis and had to answer 37 questions in a preoperative questionnaire and 34 questions in a postoperative one and we extracted 15 questions from each of the questionnaire. Results: Statistics show that there was an improvement in quality of life as reported by $77.78 \%$ of interviewers, libido and sexual quality were improved in $44 \%$ of the included patients and a level of stress considered responsible for food hyperapetitis in only about $43 \%$ of respondents. Conclusions: Improving the quality of life is directly related to weight loss. In addition, there is a correlation between improving the quality of life and improving sex life or increasing the frequency of exercise. Metabolic surgery must be understood with all the benefits it generates.
\end{abstract}

Keywords: to live, to eat, metabolic, surgery, obesity, behavior.

\section{Rezumat}

Introducere: Obezitatea este în prezent o problemă endemică la nivel mondial cauzată în mare măsură de un mediu care promovează consumul excesiv de alimente și descurajează activitatea fizică. Sursele obezității sunt direct legate de două domenii: factorii genetici și de mediu, care interacționează constant în reglarea greutății corporale.

Scop: Prin această cercetare, s-a urmărit evaluarea profilului tipic al individului care apeleaza la chirurgia metabolică și gradul de satisfacție fizică și psihologică după o astfel de intervenție. Materiale și metode: Pacienții introduși în studiu provin din cazuri personale, în număr de aproximativ 1130, operați pe parcursul a 9 ani. Dintre acestea, 122 au reprezentat baza analizei și au trebuit să răspundă la 37 de întrebări într-un chestionar preoperator și la 34 de întrebări într-unul postoperator și am extras 15 întrebări din fiecare chestionar. Rezultate: Statisticile arată că a existat o îmbunătățire a calității vieții, așa cum a fost raportat de 77,78\% dintre participanti, libidoul și calitatea sexuală au fost îmbunătățite la 44\% dintre pacienții incluși și un nivel de stres considerat responsabil pentru apetitul alimentar crescut la doar aproximativ 43\% dintre respondenți. Concluzii: Îmbunătățirea calității vieții este direct legată de pierderea în greutate. În plus, există o corelație între îmbunătățirea calității vieții și îmbunătățirea vieții sexuale sau creșterea frecvenței exercițiilor. Chirurgia metabolică trebuie înțeleasă cu toate beneficiile pe care le generează.

Cuvinte cheie: a trăi, a mânca, metabolic, chirurgie, obezitate, comportament.live, eat, metabolic, surgery, obesity, behavior.

'Medicover Hospital, Bucharest, Romania

${ }_{\text {n }}$ Sf. Ioan" Emergency Clinical Hospital, Bucharest, Romania

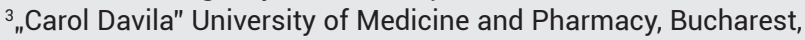
Romania

\section{Corresponding author:}

Radu Mihail MIRICA, „Sf. Ioan” Emergency Clinical Hospital,

"Carol Davila" University of Medicine and Pharmacy, Bucharest, Romania.

E-mail: mirica_rm@yahoo.com 


\section{INTRODUCTION}

Obesity is currently an endemic problem worldwide, the origins of which are studied by the most diverse disciplines. The sources of obesity are directly related to two areas: genetic and environmental factors, which constantly interact in the regulation of body weight.

In general, heredity of obesity is to be responsible in a range of $40 \%-70 \%$. As a miscellaneous fact, it has been found that over 244 genes affect the fat layer when over expressed or down regulated in mice. These genes can be considered in four broad categories ${ }^{1}$ :

- regulation of food intake by molecular signaling in the hypothalamus and cerebellum through signals from adipose tissue, intestine and other organs;

- regulation of adipocyte differentiation and fat storage;

- regulation of daily physical activity;

- effect on basal and postprandial thermogenesis ${ }^{1}$.

The most convincing evidence for a genetic component of obesity comes from studies on twin brothers and studies on adopted children ${ }^{1-4}$. In studies in which body fat content was measured (either as body mass index [BMI] or as fat thickness), the comparison in homozygous twins and heterozygous twins indicated heredity coefficients ranging from 0.4 to 0.98 (where 0 $=$ no inheritance and $1.0=$ complete inheritance of the trait). A genetic component of obesity has also been confirmed in adoption studies ${ }^{3}$. These comparisons indicate that the genetic transmission of obesity is at least as important as non-genetic transmission. Finally, genetic segregation analyzes ${ }^{5}$ in extended families suggest that approximately $30 \%$ to $50 \%$ of the obesity phenotype is inherited and there is evidence for a major recessive gene or genes with an allele frequency. Some obesity candidate genes have been identified 5,6 and the importance of some of them has been confirmed in genetically modified mice.

On the other hand, the current obesity epidemic is predominantly caused by circumstances that promote exaggerated food consumption and discourage physical activity. Although people have developed exceptional physiological mechanisms to protect themselves against body weight loss, these mechanisms are weak against body weight gain when foods are present in abundance. Controlling portion sizes, eating a low-fat, low-calorie diet and adopting a regular physical activ- ity routine are behaviors that defend against obesity. After all, it is proving difficult to embrace and keep these behaviors in today's environment. As obesity is crucial to treat, public health policy efforts must be directed towards prevention.

The most common metabolic surgery procedures are the adjustable gastric band, longitudinal gastrectomy (gastric sleeve) and gastric bypass. The adjustable gastric band is a restrictive, reversible procedure, the band can be extracted at a certain period after weight loss has been achieved. Longitudinal gastrectomy involves the removal of $60-70 \%$ from the stomach, practically keeping a gastric tube that continues the esophagus. Gastric bypass involves a short circuit of the digestive tract, which prevents food from being exploited by resources to its full potential, which leads to this technique being placed in the malabsorptive category.

\section{AIM}

Through this research, it was aimed to evaluate the typical profile (age, sex, eating habits, access to specific information needed for the decision to appeal to surgery, eating habits before intervention) of the individual who uses metabolic surgery, the degree of satisfaction physically and psychologically after such an intervention.

The present research aims at analyzing data collected through two questionnaires and the personal $\mathrm{Eu}-$ ropean database (EAC-BS European Accreditation Council for Bariatric Surgery - which prospectively studies the results of metabolic surgery and provides accreditation to specialized centers) offered to supplement patients who have appealed to metabolic surgery within 2 years (2019-2020).

\section{MATERIALS AND METHODS}

The patients introduced in the study are from personal cases, in number of about 1130, operated during 9 years. Of these, 122 represented the basis for the analysis and had to answer 37 questions in a preoperative questionnaire and 34 questions in a postoperative one. In total, we extracted from the questionnaires, for the present research, 15 questions of the 37 preoperative questionnaire and 15 of the 34 of the postoperative one. The questionnaires were sent to patients personally at the end of the consultation or by email. From these questionnaires were extracted the questions from which results the following information followed in the research: 
- patient demographics (gender, age groups);

- preoperative life and eating behavior;

- postoperative life and eating behavior.

Candidate patients for metabolic surgery procedures met the inclusion criteria set by the International Federation for Obesity Surgery (IFSO) established at the Consensus Conference of the American Obesity Surgery Association in 2004 and the European Endoscopic Surgery Association in 2005:

- $\mathrm{BMI}>40 \mathrm{~kg} / \mathrm{sqm}$;

or

- $\mathrm{BMI}>35 \mathrm{~kg} / \mathrm{sqm}$ accompanied by important associated diseases (hypertension, heart failure, sleep apnea syndrome, respiratory failure, bilateral gonarthrosis);

- history of obesity over 5 years;

- failure of conservative medical treatments for obesity;

- age 18-60 years.

The analysis is a retrospective based on a group of 122 obese patients operated on, of which 34 in St. John's Emergency Hospital, 88 in Medicover Hospital both in Bucharest, who underwent metabolic surgery (stomach reduction and bypass). All patients were interviewed both before and after the operation.

\section{RESULTS}

The research included 122 patients in the study $(25 \%$ men and 75\% women), aged between 18 and 67 years (Figure 1). Regarding the distribution according to sex by age groups, we observe a majority number of all age groups among female patients, it is known that women use this type of surgery much more frequently, compared to men. There are several possible explanations.

First of all, women are more concerned with aesthetics. During pregnancy, they also have the opportunity speculated by many of them to have a high weight gain that they later fail to lose. This explanation also correlates with the peak age found in the range of 20 29 years. Thus, most patients are young at 3-18 months after giving birth and who not only did not lose the excess gained in pregnancy but also increased it.

To the question "since when do you have weight problems?" it is obvious that the majority of patients are those with a long history of weight problems, the decision to apply for surgery being taken for most of the respondents following numerous conservative at-

\section{EAC-BS}

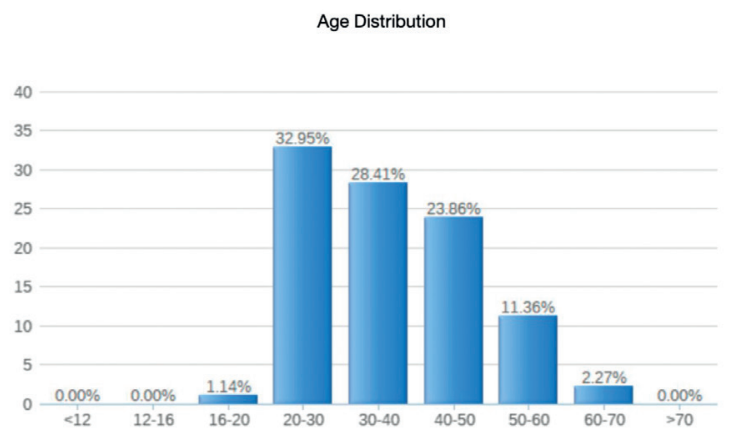

Figure 1. Age distribution - The majority age group was 20-30 years old, followed by the $30-40$ and $40-50$ age groups. These are in the target of bariatric patients.

tempts to lose weight through diets.

As a supplement to the previous question comes „What has been the density of diets so far?" (Figure 2) which shows that out of the total respondents only $19 \%$ had not tried any form of diet until the time of surgery, about $65 \%$ of them had been „numerous” and „always" as the frequency of diets.

An important element in sketching eating habits is

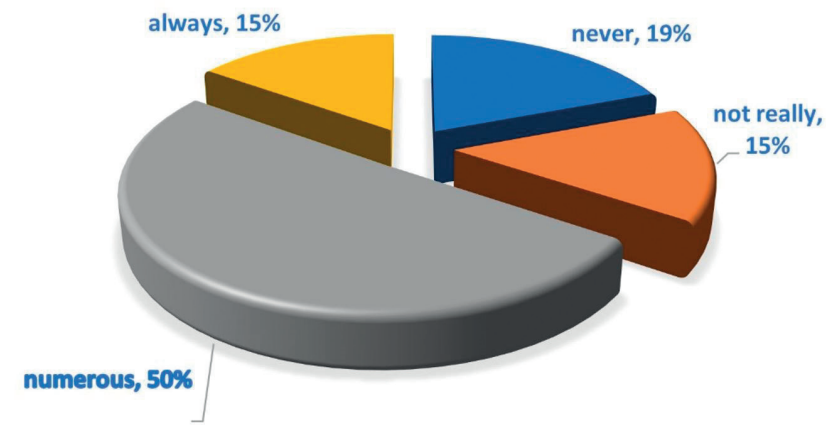

Figure 2. „What has been the density of diets so far?” The graphic shows that out of the total respondents only 19\% had not tried any form of diet until the time of surgery, about $65 \%$ of them had been „numerous” and „always” as the frequency of diets.

the number of daily meals, the habit of eating between meals and also what they usually have for snacks. Thus, the answers to the question showed that more than half of the respondents, $56 \%$ have 3 or more meals but even more interesting is the fact that $78.8 \%$ (Figure 3) usually eat between main meals. 


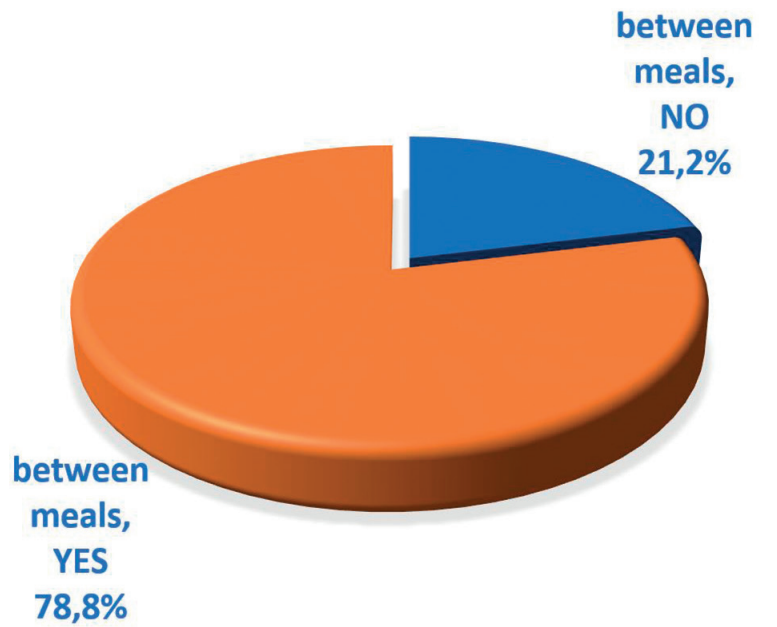

Figure 3. The presence of intermediate meals between main meals $-78.8 \%$ usually eat between main meals.

The answers regarding the caloric quality of favorite foods bring to light the biggest "culprits" of high-calorie intake: sweets and sweet drinks, $40-48 \%$ of the respondents state that the above two are preferred, assuming in terms of experience and daily discussions that the consumption of the two is daily.

The low consumption of vegetables is noticed negatively (Figure 4 ), with only $8 \%$ of patients stating that they prefer them. Among the essential foods of a diet, it is recommended the consumption of 200-300 grams of fruits/vegetables daily.

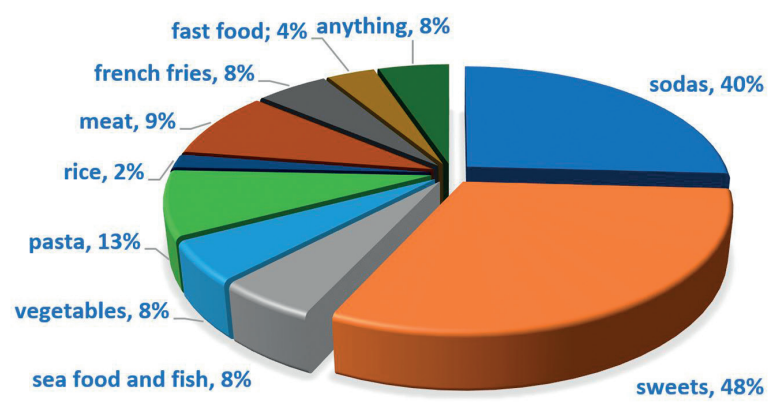

Figure 4. Type of food consumed - Most obese patients have a diet rich in sodas and sweets.

The present research shows a level of stress considered responsible for food hyperapetitis in only about $43 \%$ of respondents (Figure 5). The question, however, could only interrogate the personal perception of stress and did not involve biochemical measurements of the body's real stress level.

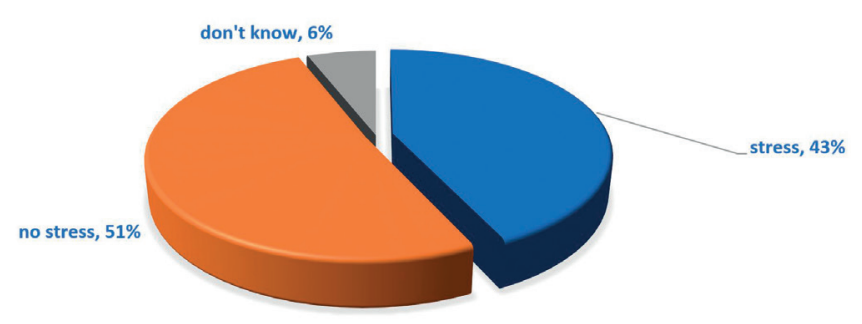

Figure 5. Stress level - the personal perception of stress

The BMI (Figure 6) is the easiest tool for assessing weight status. Before the surgical treatment, approximately $41 \%$ of the patients were grade III of obesity $(\mathrm{BMI}>40 \mathrm{~kg} / \mathrm{sqm})$, on the second place being those with grade I obesity and only on the third place those with grade II obesity. It can be speculated that about half had serious weight problems, knowing that after this grade, comorbidities appear. Somewhat surprising is the second place of those who have just entered the category of obese. The speculation here may be that there is already a form of prevention of severe obesity, especially among women who as soon as they have passed the obesity threshold, they do everything so the weight does not progress.

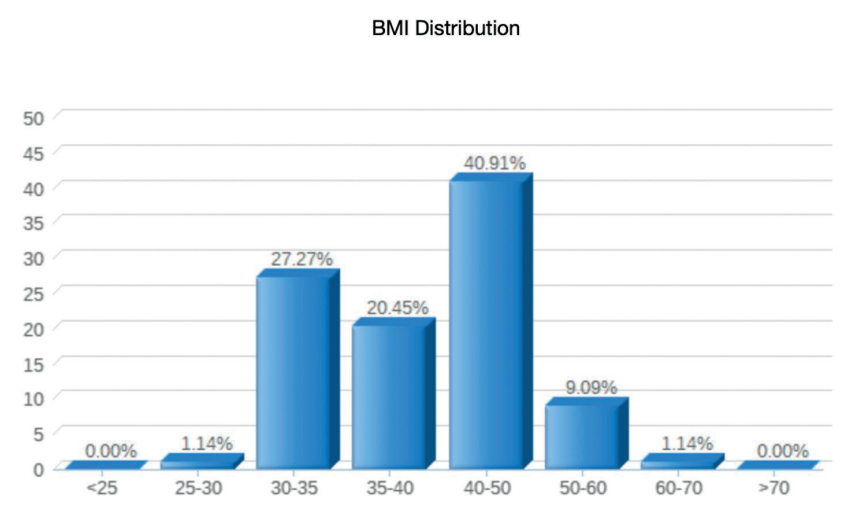

Figure 6. BMI Distribution - Before the surgical treatment, approximately $41 \%$ of the patients were grade III of obesity (BMI $>40 \mathrm{~kg} / \mathrm{sqm}$ ), on the second place being those with grade I obesity and only on the third place those with grade II obesity

Interesting results were obtained for weight loss at the intervals used for follow-up. Thus, as can be easily seen (Figure 7) at 12 months, when weight loss by these methods stops, patients had lost excess weight. The reference value is EWL (excess weight loss) and is thought of as a percentage of the excess present at the time of intervention. 


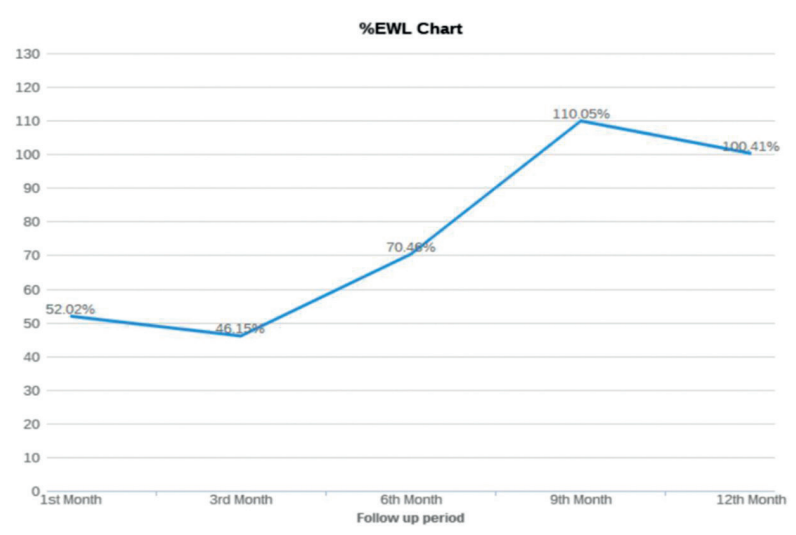

Figure 7. \%EWL Graph - the evolution of $\% \mathrm{EWL}$ - with an increase up to $110 \%$ of $\% \mathrm{EWl}$ at $9-12$ months

An important aspect (Figure 8) is the volume of food that can be ingested after the operation. The reduction in volume was maximum after the intervention but gradually increased over time, but this is not the most important argument in the recurrence of obesity.

\section{Reducing the amount of food consumed postoperatively}

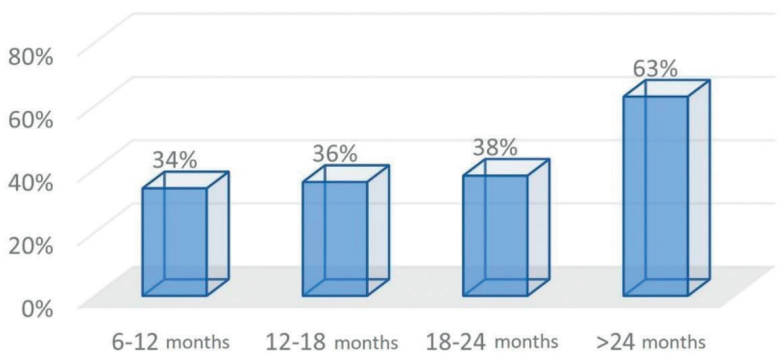

Figure 8. Food consumed postoperatively - the amount of food consumed postoperatively increased with approximately $30 \%$ at 24 months

From the patients, included in the research, $44 \%$ developed an aversion to certain foods (eggs, meat, milk/cheese and sometimes some sweet foods). Usually, food aversions develop shortly after surgery but will diminish or vanish over time. In some studies, animal protein tops this list, with patients avoiding meat (chicken, beef, pork, lamb or sausages). Dairy products which include milk, cheese and ice cream, eggs, bread, rice and pasta were also at the top of the list of avoided foods. Not surprisingly is the fact that a small number of patients reported aversion to vegetables or fruits.
Most patients improved both their athletic performance and the frequency of exercise. Patients who had a high BMI began to practice sports after becoming almost normal. Most patients have more intense physical activity than before surgery. The percentage of those who perform less exercise than before is close to 0 .

Most patients maintained the same level or improved their sexual status (Figure 9). Libido and sexual quality were improved in $44 \%$ of the included patients (scale 4 'better' or scale 5 - 'best').

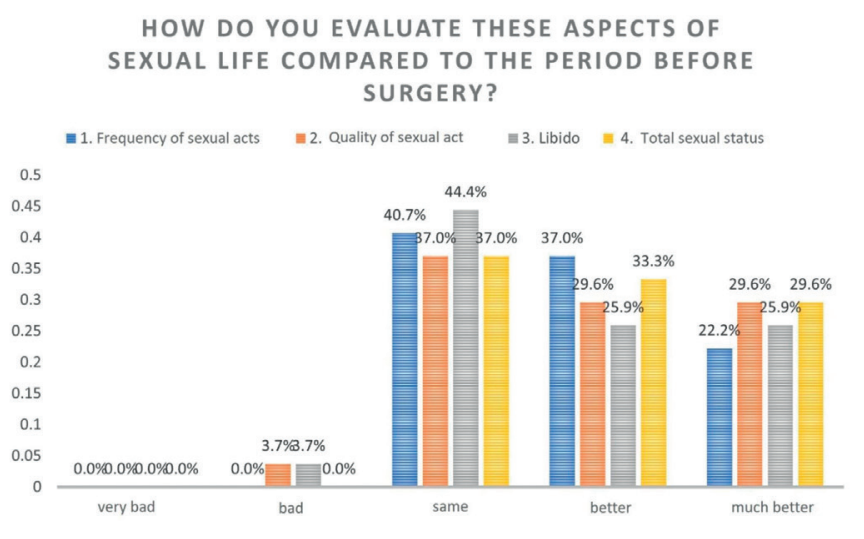

Figure 9. Quality of life after surgery. After surgery most patients had a much-improved quality of life.

No patient interviewed changed his social status. The situation of each patient in the relationship with his life partner had only to gain, either by improving sexual status or physical activity or by self-confidence and lack of frustration caused by obesity.

Also, there was an improvement in the quality of life as reported by $77.78 \%$ of interviewers, $11 \%$ had a good quality and only $3.7 \%$ said that life lost quality compared to the period before surgery. The improvement in quality of life was directly correlated with weight loss. There is also a direct relationship between quality of life, improved sex life and increased frequency of exercise (Figure 10).

The impact of the surgical interventions (preoperative procedure, surgical stress and postoperative recovery) was considered very small in approximately $62.96 \%$ of those surveyed. This is explained by the minimally invasive laparoscopic approach of these interventions, all patients having such an approach. Only $3.7 \%$ of patients considered the operation to be very stressful. 


\section{Life quality after surgery}

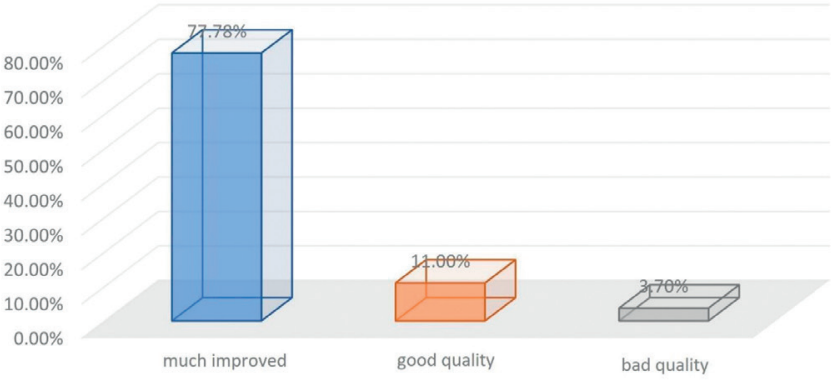

Figure 10. Quality of life after surgery. After surgery most patients had a much-improved quality of life.

\section{DISCUSSIONS}

Various studies ${ }^{7}$ finally shed light on the confusion about a possible link between BMI and men's marital status. There are several competing theories about what happens to weight when people get married. The findings support the so-called "marriage market theory" that people who are single but intend to get married feel stimulated to stay in shape, putting in more effort than married people. Also, the same cited study supports another idea, the "theory of social obligation” according to which marriage leads to the fact that men eat more regular meals and participate in more social events where food is served.

One concept that has gained researchers' attention is that foods, especially those that are hyper-palatable (hyper-tasty, high in fat, high in sugar), can lead to a form of addiction. Researchers call hyperpalatables processed foods or sweets with attractive combinations of fats, sugar, carbohydrates and sodium, foods with a very strong taste in the good sense.

While a lot of documentaries, books and academic studies have addressed hyper-tasting foods in the last 15 years, none have yet provided a widely accepted definition of what constitutes hyper-tasting foods.

In 2014, EUROSTAT showed a worrying aspect: Romania ranks last in the European Community in terms of consumption of vegetables and fruits, with only $35 \%$ of the population consuming such foods daily 5 .

The risk of metabolic diseases is increased by stress which is well known to create addiction. When it is not controlled, stress can boost the consumption of hyper palatable foods and can also change eating patterns. Compulsive behavior can be developed over time because of neurological adaptations caused by stress. These adaptations will be mediated by changes in the appetite-related hormones, hypothalamic-pituitary-adrenal axis (HPA), insulin sensitivity and glucose metabolism. The dopaminergic system and some regions of the brain implicated in stress and motivation circuits can be affected by chronic stress and can enhance the desire and search for hyper palatable foods, reward sensitivity and induce metabolic changes that promote weight gain.

Patients can develop aversion to food from reasons like consistency, appearance or smell. Simple changes in the method of preparation, such as cooking meat instead of baking it or frying it in a pan can reduce aversion.

The biggest benefit of metabolic surgery is not only weight loss, but especially the social benefits that occur with weight loss that this approach involves. Some patients require surgery to lose weight by ingesting less food and feeling less hungry because the desire to do so without surgery is not easy. However, patients must understand that surgery is a curative act, not a preventive one, and is only an initial tool and later they must take responsibility for maintaining long-term results.

Even though food intake 2 years after surgery increased by about $30 \%$. Boan study ${ }^{8}$ has shown that this causes the weight to stabilize at a normal value. There are reports in the literature that have shown an increase in the amount of food and weight after 6 years of surgery ${ }^{9}$, increases that have led to a very small percentage to a significant increase in BMI.

The psychosocial benefits of metabolic surgery have an important role in improving quality of life and social reintegration. Obesity is a suffering not only because of the risk of associated comorbidities, but it is also the cause of many daily frustrations. In addition, it can interfere with the emotional state of the individual. Surgical treatment of obesity not only provides an improvement in quality of life, but also the social, emotional, psychological and family reintegration of the individual. In addition, metabolic surgery provides an improvement in the quality of sex life in obese patients, with increasing the frequency and quality of sexual intercourse, libido and erectile function.

Changes in self-image and self-esteem that occur after metabolic surgery undoubtedly have a positive influence on patients' quality of life. Many of the patients surveyed (over 90\%) said they were very satisfied after the operation and wanted to recommend this intervention to other obese people. Also, the incidence of depression associated or not with elements of suicide attempts is much lower among operated patients who 
have lost weight without changing the environment, entourage or social status ${ }^{10}$.

An important feature of this research is that we used a personalized questionnaire for a typology of bariatric patients in Romania. To our knowledge and from the study of literature, such a personalized questionnaire has not been used so far in Romania. One of the limitations of this research is the small number of cases included. Even if the total number of surgeries is much higher, the number of postoperative questionnaires obtained is small, due to non-compliance with the requirements of postoperative follow-up by patients. Another limitation is represented by the subjective evaluation of these questionnaires, as they cannot objectively evaluate various parameters.

\section{CONCLUSIONS}

To summarize, the typical patient who enters the clinic for metabolic surgery services is a woman in the 3rd decade of life, after a pregnancy, overweight for about 10 years and who has failed to lose weight with methods that involve diet and sports. The financial status is high (the operations being expensive) but without necessarily registering an above average education status. It is well known that obesity is high in financially disadvantaged environments and decreases with the level of education, individuals being more motivated to live healthy once they can afford it and have access to relevant information.

Most people have not only changed their appearance or way of eating, but they have changed the way they see life as a whole, now smiling more, laughing more, having a more colorful wardrobe and the urge to socialize more.

Improving the quality of life is directly related to weight loss. In addition, there is a correlation between improving the quality of life and improving sex life or increasing the frequency of exercise. The minimally invasive approach of metabolic surgeries allows the rapid reintegration of the individual into daily activities. Metabolic surgery must be understood with all the benefits it generates. Interesting to return to the data over 5-7 years with the possible surprise of changes that occurred.

Compliance with ethics requirements: The authors declare no conflict of interest regarding this article. The authors declare that all the procedures and experiments of this study respect the ethical standards in the Helsinki Declaration of 1975, as revised in 2008(5), as well as the national law. Informed consent was obtained from all the patients included in the study.

\section{References}

1. McPherson R. (2007). Genetic contributors to obesity. The Canadian journal of cardiology, 23 Suppl A(Suppl A), 23A-27A. https:// doi.org/10.1016/s0828-282x(07)71002-4

2. Bodurtha JN, Mosteller M, Hewitt JK, et al. Genetic analysis of anthropometric measures in 11-year-old twins: The Medical College of Virginia Twin Study. Pediatr Res. 1990;28:1-4.

3. MacDonald A, Stunkard A. Body-mass indexes of British separated twins. N Engl J Med. 1990;322:1530.

4. Stunkard AJ, Sorensen TI, Hanis C, et al. An adoption study of human obesity. N Engl J Med. 1986;314:193-8.

5. Stunkard AJ, Harris JR, Pedersen NL, McClearn GE. The body mass index of twins who have been reared apart. N Engl J Med. 1990;322:1483-7.

6. Distribution of persons aged 15 and over according to the number of portions of fruit and vegetables consumed per day, 2014 or nearest year (\%)Source: Eurostat (hlth_ehis_fv3e)

7. Tera L. Fazzino, Kaitlyn Rohde, Debra K. Sullivan. Hyper Palatable Foods: Development of a Quantitative Definition and Application to the US Food System Database. Obesity, 2019; 27 (11): 1761 DOI: 10.1002/oby.22639

8. DANIEL T. LICHTER, ROBERT N. ANDERSON, MARK D. HAYWARD Marriage Markets and Marital Choice First Published July 1, 1995 Research Article doi:10.1177/019251395016004001

9. Quality of Life and Physical Activity Improve after Roux-en-Y Gastric Bypass for Morbid Obesity Jarol Boan, MD, MPH1; Ronette L. Kolotkin; Eric C. Westman; Ross L. McMahon, John P. Grant, Obesity Surgery, 14, 341-348 Binge Eating,

10. Dirk P. A. Versteegden Magaly J. J. Van himbeeck. Assessing the value of eHealth for bariatric surgery (BePatient trial): Study protocol for a randomized controlled trial. Trials $2018 \mathrm{Nov}$ 14;19(1):625 doi: 10.1186/s13063-018-3020-x

11. James E. Mitchell Wendy C. King Jia-Yuh Chen Michael J. Devlin David Flum Luis Garcia William Inabet John R. Pender Melissa A. Kalarchian Saurabh Khandelwal Marsha D. Marcus Beth Schrope Gladys Strain Bruce Wolfe Susan Yanovski Course of depressive symptoms and treatment in the longitudinal assessment of bariatric surgery (LABS-2) study Obesity (Silver Spring) 2014 Aug;22(8):1799-806. doi: 10.1002/oby.20738 